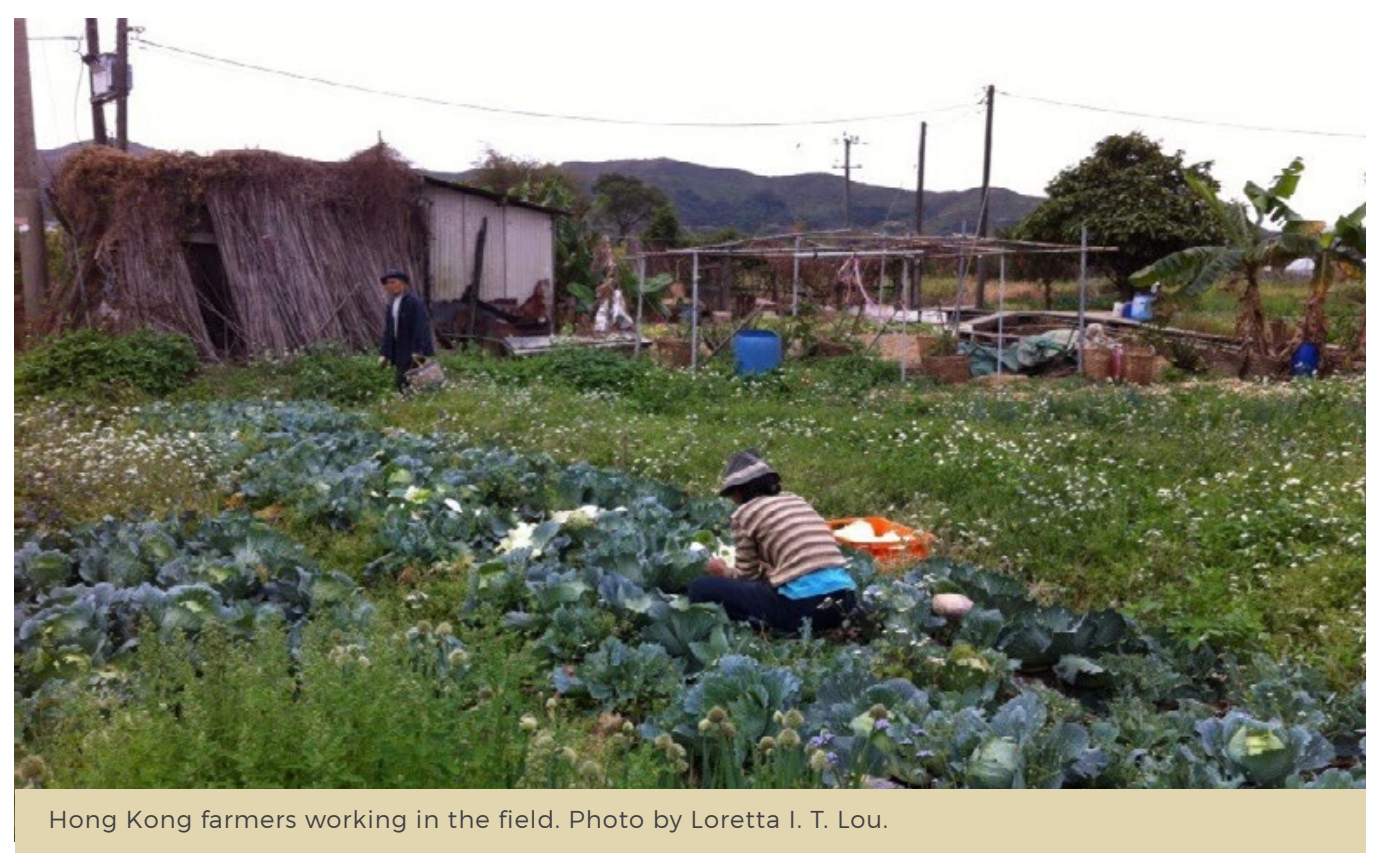

\section{In the Absence of a Peasantry, What, Then, Is a Hong Kong Farmer?}

\section{Loretta leng Tak Lou}

Given the social and political significance of 'the peasant' (nongmin) in modern Chinese history, it is surprising that the term (nongmin) is largely absent in Hong Kong, where discourses about individual farmers (nongfu) are far more prevalent. In tracing the modern etymology of Chinese peasants and the history of Hong Kong agriculture, this essay argues that the lack of 'class' consciousness makes Hong Kong farmers even more vulnerable to the unceasing wave of urban sprawl.
Given the significance of 'peasants' (nongmin) in recent Chinese history, I was surprised to find that the term nongmin is pretty much absent in Hong Kong, where I have been researching the local green living movement since 2012. In China, nongmin is an expression of social and political importance. Since the establishment of the People's Republic of China (PRC) in 1949, the term nongmin not only refers to people whose livelihoods depend on agriculture, but is also incorporated into China's administrative classification, along with other status groups such as workers (gongren) and urban residents (jumin) (Cohen 1993). In her article 'What, Then, Is a Chinese Peasant?', Mindi Schneider (2015) demonstrates that nongmin is a complex and multi-layered concept of multifarious meanings. For example, when it is a legal and administrative category, nongmin reflects the rigid separation between rural and urban hukou. As a cultural signifier, the term connotes 'low quality' and 'backwardness'. Indeed, Chinese peasants 
have been increasingly made the scapegoat for China's food security and food safety problems (Schneider 2015). As such, although the peasantry is an indispensable part of the political discourse and economic development in the $\mathrm{PRC}$, they remain one of the most socially marginalised groups in China today.

\section{In Search of a Hong Kong Peasantry}

Although the term nongmin can be found sporadically in writing, I have never heard people in Hong Kong, including those who actually engage in farming, use it in conversation. Instead, local people use 'farmer' (nongfu) to refer to individuals who plant vegetables and fruit. Depending on where, how, and why they farm, those engaging in agricultural activities in Hong Kong can be further differentiated into urban farmers (dushi nongfu), organic farmers (youji nongfu), and leisure farmers (jiari nongfu), as well as others (Cheng 2009b).

Obviously, the vastly different historical trajectories of China and Hong Kong contribute to the lack of nongmin discourses in the former British colony. One reason that the expression is not more prevalent in Hong Kong has to do with how the term was constructed and loaded with its current meanings in mainland China during the twentieth century. According to Myron Cohen (1993), nongmin was one of the many loanwords from Japan that entered China during the late nineteenth and early twentieth centuries. Like other similar linguistic imports that were borrowed to express the flood of new ideas and new social phenomena at that time (Chen 2014), nongmin was a 'modern word' that was readily available for cultural and political elites to assign new meanings to it (Cohen 1993). Before then, the word was nowhere to be found even in the most authoritative Chinese-English dictionaries. Indeed, individuals who worked in the farm were more commonly referred to as nongfu, nongding, nongjia, and nongren (translated into English as farmers, labourers, agriculturalists, etc.). As the rural population came to be known as nongmin in the mid-twentieth century, the term was constructed as a major obstacle to national development. However, under the influence of Marxism, nongmin uprisings had come to represent a major revolutionary force that had the potential to overthrow the old feudal society.

Due to Hong Kong's colonial past, local farmers (nongfu) were not subjected to this radical 'nongmin project'. It could be said that Hong Kong farmers' identities more closely resembled Chinese farmers before the mid-twentieth century, in that they were primarily tied to agricultural work and the household without the class and revolutionary referent (Schneider 2015). Indeed, archival records suggest that during the 1920s and 1930s, Hong Kong farmers' household economy, housing arrangements, and social practices differed little from their counterparts in Guangdong before the advent of the Communist's 'nongmin project' (Hayes 2006, 13). Although many traditional Chinese customs had begun to fade away in urban Hong Kong and in mainland China, especially after the Communist revolution of 1949, peasant practices were preserved in rural New Territories well into the $1970 \mathrm{~s}$ (Carroll 2007, 71).

\section{Trials and Tribulations}

Up until the 1960s, farming provided a means of livelihood for the majority of the indigenous inhabitants, as well as the thousands of mainland Chinese refugees who settled in the New Territories as rice, vegetable, and livestock farmers in 
the aftermath of World War II and the Chinese Civil War (Kadoorie Agricultural Aid Association 1982). After the wars, subsistence agriculture was actively promoted by the colonial government and the Kadoorie Agricultural Aid Association (KAAA), a charity founded in 1951 by Lawrence and Horace Kadoorie to alleviate poverty and create social stability. Working with the Agricultural and Fisheries Department, KAAA provided money and introduced various assistance programmes to Chinese refugees, such as setting them up as pig farmers and offering them interest-free or low-interest short-term loans. The Kadoorie brothers believed that philanthropy alone was not enough, so the goal of their organisation was to help the new arrivals to stand on their own feet and become self-sufficient farmers. And they succeeded. As the Chinese refugees settled in their new home and farms in the New Territories, they supplied an ever-growing percentage of the colony's food (Hayes 2006, 29). At one point during the leftist riots in 1967, the self-sufficiency rate of locally grown vegetables peaked at 48.8 percent after the PRC curtailed food supplies to Hong Kong, forcing the colonial government to rely heavily on local produce (Lau 2013, 1 and 58).

Beginning in the late 1950s, Hong Kong's subsistence agriculture came to an end when paddy rice farming went into a sharp decline (Hayes 2006, 75-79). What is interesting, though, is that following the demise of paddy rice farming, there then came what Hoi Lung Lau describes as 'the most prosperous period of Hong Kong agriculture' in the early 1970 s and early 1980s (2013, 65). In addition to the growing demand for fresh vegetables and flowers from the urban middle class, Lau believes that the superior quality of Hong Kong vegetables accounted for the agricultural boom. As his interviewee vividly recalled: 'As Chairman Mao made them put all the effort into growing grains, farmers in the mainland had gotten out of practice of growing tasty vegetables!' $(2013,69)$.

Unfortunately, this golden era of agriculture did not last long. At first, farms were hit by labour shortages as villagers in the New Territories sought higher paid manufacturing and office jobs in the city. Later, when China opened up its market in 1978, manufacturing factories were relocated to China while Hong Kong repositioned itself as Asia's financial hub with a thriving real estate market. Consequently, many farms were lost to urban sprawl and the total area of arable land continued to decrease. Meanwhile, the increased import of food from China caused Hong Kong's food self-sufficiency rate to plummet dramatically, driving local agriculture to the brink of extinction. By the 1980s, Hong Kong no longer produced rice. Although fresh vegetables are still grown in the New Territories, the total proportion of local vegetables declined from 40 percent in the 1960 s to 2.3 percent in 2013 (Lau 2013, 1; Cheung 2014, 1019). Today, 90 percent of the food supply in Hong Kong is imported, with the majority of it from the PRC.

\section{The Emergence of a New Kind of Farmer}

As incidents of food scandals soar in China, Hong Kong people have become increasingly concerned about their heavy dependence on China for their food supply. While other factors, such as the rise of local consciousness (Hung 2014), are also responsible for the Agricultural Revitalisation Movement (fugeng yundong), food safety is no doubt a major catalyst. With help from land activists, environmentalists, and local food consumers, Hong Kong farmers have joined in the movement against unbridled urbanisation and unchecked developmentalism. Even though the farmers usually prefer to take a back seat and let the 
activists do the actual organising, during the process of mobilisation, farmers in Hong Kong have learned to redefine their social and cultural identity by emphasising their contribution to sustainability and their role as defenders of Hong Kong's remaining farms.

In contrast to the nongmin in China, who continue to suffer from all kinds of stigma and discrimination, nongfu in Hong Kong seem to have overcome the bias that farming is an inferior occupation (Lau 2013, 72). Since the first mobilisation against landgrabbing in 2008 (also known as the 'Choi Yuen Village Incident', see Chang 2010), Hong Kong farmers have assumed a more dignified image. Today, farmers in Hong Kong no longer consider agriculture as an obstacle to Hong Kong's socioeconomic development-a metanarrative that has held strong until very recently. Rather, they have come to see agriculture as an indispensable element of the city, an idea that was clearly articulated during the first Hong Kong Agricultural Forum in 2013.

\section{Farmers without Class Consciousness}

Despite their new cultural identity, Hong Kong nongfu do not wield any more political power than the nongmin in the PRC. In a way, Hong Kong farmers could face extinction even sooner because they lack the class consciousness that unifies the peasantry in China. After all, it is much easier to eliminate some 4,600 farmers, most of which are tenants without land ownership, than to eliminate an entire peasant 'class' without causing some social unrest. Moreover, despite their close affinity with land activists, in reality Hong Kong farmers lack political power to influence agricultural policies. For one, their 'professional representative' in the Legislative Council is elected by a small group of elite members, who are ardent partisans of the government's pro-growth developmental strategies.

To pacify farmers and to show governmental commitment to supporting local agriculture, the government inaugurated a Hydroponic Centre in 2013 to promote the benefits of growing vegetables in a controlled environment. While vertical hydroponics appears to support local agriculture and responds to Hong Kong people's increasing demand for 'clean vegetables', the practice is highly unpopular among farmers in the New Territories, who see it as a plot to uproot them from their land, allowing the government to continue to push forward its urbanisation agenda. Speaking at the Hong Kong Agricultural Forum in 2013, TV, a farmer at the Ma Po Po Community Farm, made an analogy between farmers and vegetables on a plate of barbecued pork rice (char siu faan): 'Unorganised farmers are like the two pieces of side vegetables on the plate. Finance and real estate are the barbecued pork and we all want more of that. However, we also know that eating too much meat is no good for our health, so we add two pieces of vegetables on the side. The side vegetables are like our farmers and our local agriculture. They are good on display, but they are dispensable.' Indeed, Hong Kong farmers may have escaped the stigma and discrimination associated with their nongmin counterparts in the PRC, but in a city where an inch of land is worth an ounce of gold, they might not be able to escape being devoured by the unceasing wave of urban sprawl that is bound to happen over the next fifteen years. 
This text is taken from Gilded Age: A Year of Chinese Labour, Civil Society, and Rights, Made in China Yearbook 2017, edited by Ivan Franceschini and Nicholas Loubere, published 2018 by ANU Press, The Australian National University, Canberra, Australia.

doi.org/10.22459/MIC.04.2018.31 